\title{
Ebola preparedness: a rapid needs assessment of critical care in a tertiary hospital
}

\author{
Aimee J. Sarti MD, Stephanie Sutherland PhD, Nicholas Robillard MD, John Kim MD MEd, \\ Kirsten Dupuis RN BScN, Mary Thornton RN, Marlene Mansour MD, Pierre Cardinal MD MScEpi
}

\section{Abstract}

Background: The current outbreak of Ebola has been declared a public health emergency of international concern. We performed a rigorous and rapid needs assessment to identify the desired results, the gaps in current practice, and the barriers and facilitators to the development of solutions in the provision of critical care to patients with suspected or confirmed Ebola.

Methods: We conducted a qualitative study with an emergent design at a tertiary hospital in Ontario, Canada, recently designated as an Ebola centre, from Oct. 21 to Nov. 7, 2014. Participants included physicians, nurses, respiratory therapists, and staff from infection control, housekeeping, waste management, administration, facilities, and occupational health and safety. Data collection included document analysis, focus groups, interviews and walk-throughs of critical care areas with key stakeholders.

Results: Fifteen themes and 73 desired results were identified, of which 55 had gaps. During the study period, solutions were implemented to fully address 8 gaps and partially address 18 gaps. Themes identified included the following: screening; response team activation; personal protective equipment; postexposure to virus; patient placement, room setup, logging and signage; intrahospital patient movement; interhospital patient movement; critical care management; Ebola-specific diagnosis and treatment; critical care staffing; visitation and contacts; waste management, environmental cleaning and management of linens; postmortem; conflict resolution; and communication.

Interpretation: This investigation identified widespread gaps across numerous themes; as such, we have been able to develop a set of credible and measureable results. All hospitals need to be prepared for contact with a patient with Ebola, and the preparedness plan will need to vary based on local context, resources and site designation.

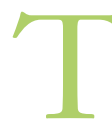
he current outbreak of Ebola began in Guinea, West Africa, with the first cases identified in March 2014. ${ }^{1}$ Since then, it has spread across borders to Liberia and Sierra Leone. These 3 countries have faced the most widespread and intense transmission. On Aug. 8, 2014, the World Health Organization (WHO) Director-General declared the outbreak to be a public health emergency of international concern. The WHO released statistics in March 2015 showing 24282 reported cases of Ebola in 9 countries, with 9976 reported deaths. ${ }^{2}$

On Oct. 6, 2014, occupational human-to-human transmission of Ebola virus disease was confirmed in Spain, when a hospital team member tested positive for the disease after caring for a patient repatriated from West Africa. ${ }^{1}$ On Sept. 30, 2014, the first case of Ebola virus disease was confirmed in the United States. Localized transmission also occurred in the US, where 3 hospital team members tested positive for Ebola virus disease after providing treatment to a patient with the disease.
Caring for a patient with Ebola leaves little margin for error. The risk of transmission may be even greater in critically ill patients given the heightened potential for contact with body fluids (e.g., diarrhea, vomiting, hemorrhage and the need for invasive procedures). It is essential that systems, processes, knowledge and skills be in place to safely care for these patients. In a recent publication on Ebola preparedness, Gostin and colleagues ${ }^{3}$ raised important concerns regarding health system preparedness for public health emergencies. The authors highlighted the need for research on identifying system-level gaps and weaknesses, stating that "insufficient

Competing interests: None declared.

This article has been peer reviewed.

Correspondence to: Aimee Sarti, asarti@toh.on.ca

CMAJ Open 2015. DOI:10.9778/cmajo.20150025 
funding in a research and data infrastructure limits the ability to identify weaknesses and learn from mistakes." ${ }^{3}$

On Oct. 18, 2014, the Ontario Ministry of Health and Long-term Care designated 12 centres across the province of Ontario, Canada, as Ebola patient care sites, including The Ottawa Hospital, an academic tertiary centre. When The Ottawa Hospital received this designation, it was quickly recognized that the current system and practices of providing critical care were likely insufficient to meet the demands of caring for these patients. Past experiences with caring for patients with severe acute respiratory syndrome (SARS) and H1N1 revealed numerous challenges in the provision of critical care and highlighted the importance of planning and preparedness. ${ }^{4,5} \mathrm{We}$ therefore decided to embark on a needs assessment, which compares "what should be" done to "what is" done. A need or gap is defined as a discrepancy between what is and what should be done. ${ }^{6}$

In this article, we present the results of a rigorous and rapid interdisciplinary needs assessment conducted at a tertiary hospital to clearly identify the desired results ("what should be" done), gaps in current practice, and the barriers and facilitators to the development of solutions. The scope of the needs assessment was bounded to include any aspects of critical care related to suspected or confirmed cases of Ebola. This needs assessment was performed under the assumption that we would have only a small number of suspected or confirmed cases of Ebola. If the number of cases were to be greater, the plan would require reassessment and revision.

\section{Methods}

This study was conducted at a tertiary level, academic intensive care unit (ICU) in Ontario, Canada. The ICU had 28 beds and was a mixed medical-surgical unit staffed by 2 intensivists with an integrated, interdisciplinary model of care. The ICU served as the regional referral centre for patients requiring tertiary level care and admitted about 110 140 patients each month. Although the centre had recently been designated as an Ebola patient care site, considerations in caring for these patients had not been made with the original construction of the unit, and a highly infectious disease unit or area had not been established.

For this study, we employed a qualitative research model with an emergent design. With emergent design, the research plan cannot be tightly prescribed, and the data collection process may shift and change as the researcher begins to collect data. ${ }^{7}$ As such, we designed the needs assessment to be flexible and to allow for data collection methods to be selected as needed throughout the study and also to be responsive to the availability of key stakeholders, recognizing the very tight timeline to complete the assessment and the many demands on these participants. An interdisciplinary needs-assessment team was formed, and key stakeholder groups were identified. Data collection and analysis were ongoing throughout the study in an iterative process (Table 1).

This study was granted an official exemption by the chair of The Ottawa Hospital Research Ethics Board.

\section{Data collection}

Data collection occurred from Oct. 21 to Nov. 7, 2014. Data were collected from multiple sources, including document analysis, walk-throughs, focus groups and interviews. ${ }^{8-10}$

International, national and local documents were collected and analyzed. We performed MEDLINE literature searches from 1946 to present, using the search terms "ebola," "viral hemorrhagic fever," "needs assessment," "needs," "health services needs and demands," "civil defense," "preparedness," "hospitals" and "intensive care units." In addition, we identified documents through consultation with experts in critical care and infection control. Three members of the research team reviewed documents (A.S., N.R. and M.M.). International documents included guidelines, protocols and standards released by the WHO, the Centers for Disease Control and Prevention (CDC) and Emory Healthcare. ${ }^{11-26}$ Guidelines from the Canadian Critical Care Society (CCCS), the Canadian Association of Emergency Physicians (CAEP), Association of Medical Microbiology and Infectious Disease Canada (AMMI Canada), the Public Health Agency of Canada, Public Health Ontario and the Ontario Ministry of Health and Long-term Care, as well as hospital documents were included in the analysis. ${ }^{27-31} \mathrm{We}$ anticipated that these documents would change rapidly throughout the study period; hence, the research team checked frequently for updates and incorporated new information as it was released.

Walk-throughs, focus groups and interviews were performed with key stakeholder groups. During this process, we sought to gain a comprehensive understanding of "what should be" done, and to identify gaps, contextual factors, barriers and facilitators to implementation of solutions. Both purposive and snowball sampling were used. The research team identified participants through purposive sampling, which is a nonrandom technique in which the researcher seeks out individuals from the various key stakeholder groups to capture different perspectives. In addition, we used snowball sampling, in which participants themselves could identify potential participants, to identify any hidden populations that could have been initially overlooked by the research team. ${ }^{7}$ Walkthroughs were performed in the intensive care unit, emergency department and medicine wards. The line of inquiry initially began open-ended and progressively became semistructured. Mental simulation, low-fidelity simulation and flow-mapping techniques were used to help participants describe and then visualize various patient scenarios. Raw data were captured in field notes and then reviewed and processed. Through the needs-assessment period, there was also an "open door" policy, whereby anyone (e.g., nurses, physicians, respiratory therapists, housekeeping staff and infection control staff) were encouraged to approach the needs-assessment team at any time. Raw data from these informal encounters were also captured and reviewed.

\section{Data analysis}

We analyzed data using an inductive approach. In the first cycle of data analysis, we coded raw data. These data were organized directly into a matrix to facilitate analysis, which 
evolved throughout the investigation. ${ }^{10}$ In the second cycle of coding, 2 of the investigators performed pattern coding to group the codes into categories. During this process, codes were aggregated and collapsed. We also explored codes for consistency and plausibility. Disagreements were resolved through discussion to reach consensus. Finally, codes/themes were summarized as "desired results" or "what should be done," or as factors to be considered in the development and implementation of solutions (related to a desired result). Three members of the research team rated each result and assigned either "yes" for gap present or "no" for gap absent. A gap was defined as a result that was not fully addressed. ${ }^{8}$ For each gap, the team also identified specific solutions introduced during the conduct of the needs assessment. Solutions

Table 1: Time-ordered matrix of activities for the needs assessment

Key stakeholders; no. involved in activity

\begin{tabular}{|c|c|c|c|c|c|c|c|c|c|c|}
\hline \multirow[b]{2}{*}{$\begin{array}{l}\text { Date, } \\
2014\end{array}$} & \multirow[b]{2}{*}{ Activity/data collection } & \multicolumn{9}{|c|}{ Key stakeholders; no. involved in activity } \\
\hline & & 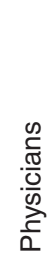 & 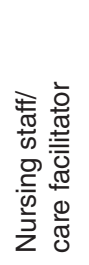 & 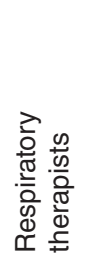 & 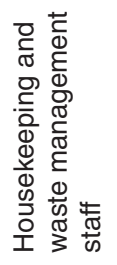 & 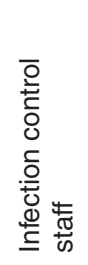 & 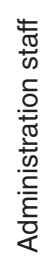 & 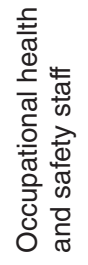 & 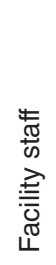 & $\frac{\grave{\Phi}}{\stackrel{ \pm}{Ð}}$ \\
\hline \multirow[t]{4}{*}{ Oct. 21} & Walk-through of ED and ICU areas & 1 & 2 & 1 & & & 3 & & & \\
\hline & Walk-through of ICU areas & 1 & & & 4 & & & & & \\
\hline & Interview with respiratory therapy lead & & & 1 & & & & & & \\
\hline & Interview with care facilitator & & 1 & & & & & & & \\
\hline \multirow{3}{*}{ Oct. 22} & Interview with nurses & & 2 & & & & & & & \\
\hline & Walk-through of ED and ICU areas & 1 & & & & & 2 & 3 & & \\
\hline & Focus group with physicians & 15 & & & & & & & & \\
\hline \multirow[t]{4}{*}{ Oct. 23} & Walk-through of ward and ICU & 1 & 1 & 1 & 2 & & 3 & & 1 & \\
\hline & Interview with physician & 1 & & & & & & & & \\
\hline & Interviews with nurses & & 7 & & & & & & & \\
\hline & Interview with pharmacist & & & & & & & & & 1 \\
\hline \multirow[t]{2}{*}{ Oct. 24} & Walk-through of simulation laboratory & & & & & & 2 & & & \\
\hline & Focus group with nurses & 2 & & & & & & & & \\
\hline Oct. 27 & Review of elements/results & 2 & 2 & & & & & & & \\
\hline Nov. 4 & Focus group & 2 & & & & 2 & & & & \\
\hline \multirow[t]{2}{*}{ Nov. 5} & Interview & & & & & 1 & & & & \\
\hline & Interviews, after PPE training & 2 & 2 & 1 & & & & & & \\
\hline \multirow[t]{2}{*}{ Nov. 6} & Focus group with respiratory therapists & & & 9 & & & & & & \\
\hline & Interviews & & & 1 & 2 & & & & & \\
\hline Nov. 7 & $\begin{array}{l}\text { Data validation - review in detail } \\
\text { completed by numerous key } \\
\text { stakeholders }\end{array}$ & 4 & 3 & 1 & 1 & 1 & 2 & & & \\
\hline
\end{tabular}


were defined as one of the following: completed (solution fully achieved the desired results), in progress (solutions partially achieved the desired result) or no solution initiated to achieve the desired result. Discrepancies were resolved through group discussion. There was ongoing work to rapidly address high-priority gaps, both systemic and educa-

Table 2 (part 1 of 3): Summary of themes and desired results

\begin{tabular}{|c|c|c|c|c|}
\hline \multirow[b]{2}{*}{ Theme } & \multirow[b]{2}{*}{ Desired results } & \multicolumn{3}{|c|}{ No. } \\
\hline & & Results & Gaps & $\begin{array}{l}\text { Solutions } \\
\text { implemented } \\
\text { for gaps* }\end{array}$ \\
\hline $\begin{array}{l}\text { Screening before } \\
\text { entry to ICU (or } \\
\text { with any ICU } \\
\text { team contact) } \\
\text { with regard to } \\
\text { transfer from ED, } \\
\text { wards, OR, } \\
\text { recovery room } \\
\text { and other } \\
\text { hospitals }\end{array}$ & $\begin{array}{l}\text { - A screening tool will be developed and kept up to date } \\
\text { - Hospital team members responsible for screening will always use the most current version of } \\
\text { the tool to screen potential cases of Ebola } \\
\text { - All hospital team members performing screening will be appropriately trained to use the most } \\
\text { secure screening process } \\
\text { - All potential cases of Ebola will be screened with the up-to-date tool and critical care hospital } \\
\text { team members will be informed of the screening test result before any physical contact occurs } \\
\text { - All patients admitted to the ICU who are from a high-risk area or have had potential contact with } \\
\text { Ebola will receive appropriate ongoing screening } \\
\text { - The screening result will be readily accessible to hospital team members }\end{array}$ & 6 & 5 & $\begin{array}{l}1 \text { yes } \\
4 \text { no }\end{array}$ \\
\hline $\begin{array}{l}\text { Response team } \\
\text { activation }\end{array}$ & $\begin{array}{l}\text { - There should be an easy and rapid way to activate a response that would not overburden } \\
\text { hospital team members who are also called on to provide care and manage the patient's } \\
\text { treatment } \\
\text { - The activation will ensure that only essential personnel are notified and expected to respond } \\
\text { - Dedicated response teams will be available to secure and manage any individual who has a } \\
\text { positive screening test for Ebola. The team will be immediately available regardless of patient } \\
\text { location or time of day }\end{array}$ & 3 & 3 & 3 in progress \\
\hline PPE & $\begin{array}{l}\text { - Hospital team members will perform a risk assessment before donning PPE } \\
\text { - There will be a clear process of donning and doffing appropriate PPE that will protect hospital } \\
\text { team members while caring for patients with potential or confirmed Ebola } \\
\text { - All equipment used in the process of donning and doffing will be available and easily accessible } \\
\text { - Hospital team members will be proficient with the donning and doffing of PPE before any } \\
\text { patient encounter or entering an Ebola precaution room } \\
\text { - Hospital team members will recognize when the clinical scenario changes and they must } \\
\text { escalate their level of PPE }\end{array}$ & 5 & 5 & $\begin{array}{l}1 \text { no } \\
4 \text { in progress }\end{array}$ \\
\hline $\begin{array}{l}\text { Managing } \\
\text { postexposure to } \\
\text { virus through } \\
\text { body fluids }\end{array}$ & $\begin{array}{l}\text { - There will be clear definition of an unprotected exposure } \\
\text { - Hospital team members will recognize when exposure has occurred } \\
\text { - Hospital team members will be proficient in taking immediate actions if exposure to body fluids } \\
\text { occurs } \\
\text { - There will be appropriate facilities available to decontaminate hospital team members if } \\
\text { exposed } \\
\text { - Hospital team members exposed to bodily fluids will be informed of the procedure to follow over } \\
\text { the ensuing days } \\
\text { - All hospital team members who help manage a patient with Ebola complete monitoring, even if } \\
\text { there was no unprotected exposure }\end{array}$ & 6 & 5 & $\begin{array}{l}3 \text { no } \\
2 \text { in progress }\end{array}$ \\
\hline $\begin{array}{l}\text { Patient } \\
\text { placement, room } \\
\text { setup, logging } \\
\text { and signage }\end{array}$ & $\begin{array}{l}\text { - The most suitable rooms to manage the treatment of patients with suspected or proven Ebola } \\
\text { will be selected and then redesigned and equipped if required } \\
\text { - Appropriate signage will be posted in the event of a suspected or confirmed case } \\
\text { - Entries and exits of all hospital team members and visitors will be logged }\end{array}$ & 3 & 2 & $\begin{array}{l}1 \text { yes } \\
1 \text { no }\end{array}$ \\
\hline $\begin{array}{l}\text { Intrahospital } \\
\text { patient } \\
\text { movement }\end{array}$ & $\begin{array}{l}\text { - Hospital team members will be able to determine the most suitable room placement for any } \\
\text { patient with suspected or confirmed Ebola } \\
\text { - Measures will be in place to optimize early recognition of deterioration of a patient's condition to } \\
\text { ensure safe transfer } \\
\text { - The transport process will be clearly defined and will only include essential staff } \\
\text { - There will be a clear and simple process to assemble the team required to transport the patient. } \\
\text { Team members involved in the transport will be readily available at all times } \\
\text { - Team members will be proficient, given their respective roles and responsibilities during the } \\
\text { transport }\end{array}$ & 5 & 5 & $\begin{array}{l}2 \text { no } \\
3 \text { in progress }\end{array}$ \\
\hline $\begin{array}{l}\text { Interhospital } \\
\text { patient } \\
\text { movement }\end{array}$ & $\begin{array}{l}\text { - The critical care team will be informed of any patient(s) with suspected or proven Ebola who } \\
\text { might require ICU admission } \\
\text { - There will be a clear process in place to ensure that the community hospitals receive all } \\
\text { necessary information to initiate safe transport } \\
\text { - There will be a plan of transport from entry point at our hospital to the ICU, which will minimize } \\
\text { the risk of contamination } \\
\text { - There will be a clear process in place to ensure that the transfer of care in the ICU occurs } \\
\text { safely for both the patient and staff }\end{array}$ & 4 & 2 & 2 no \\
\hline
\end{tabular}




\section{OPEN}

Research

tional. Solutions were developed iteratively with input from the interdisciplinary team of hospital team members and tailored to the local context. Where multiple solutions were proposed, the team discussed and, when necessary, sought more information to reach consensus before implementing a solution.

Table 2 (part 2 of 3): Summary of themes and desired results

\begin{tabular}{|c|c|c|c|c|}
\hline \multirow[b]{2}{*}{ Theme } & \multirow[b]{2}{*}{ Desired results } & \multicolumn{3}{|c|}{ No. } \\
\hline & & Results & Gaps & $\begin{array}{l}\text { Solutions } \\
\text { implemented } \\
\text { for gaps* }\end{array}$ \\
\hline $\begin{array}{l}\text { Critical care } \\
\text { management }\end{array}$ & $\begin{array}{l}\text { - Hospital team members will be supported in their decisions to withhold interventions to } \\
\text { minimize the risk of spreading infection } \\
\text { - Hospital team members will modify their clinical assessment to provide the best possible } \\
\text { patient care while minimizing the risk of contamination } \\
\text { - Hospital team members will modify noninvasive and invasive monitoring to provide the best } \\
\text { possible patient care while minimizing the risk of contamination } \\
\text { - There will be a clear process in place to perform chest radiography and electrocardiography } \\
\text { - Hospital team members will take appropriate measures to decrease the risk of exposure to } \\
\text { body fluids } \\
\text { - Hospital team members will avoid using aerosol-generating procedures whenever possible } \\
\text { - Hospital team members will take measures to safely obtain central access when required } \\
\text { - Hospital team members will safely draw blood } \\
\text { - Critical care staff will be aware of any laboratory testing that cannot be obtained for patients } \\
\text { with suspected or proven Ebola } \\
\text { - Sharps will be safely handled and disposed of } \\
\text { - Hospital team members will consider cardiopulmonary resuscitation in the appropriate setting. } \\
\text { Hospital team members will not perform cardiopulmonary resuscitation in end-stage Ebola } \\
\text { virus disease } \\
\text { - Hospital team members will consider dialysis in the appropriate setting, and measures will be } \\
\text { taken to minimize the contamination risk } \\
\text { - ECMO will not be offered in patients with proven Ebola } \\
\text { - Hospital team members will consider using nasogastric and feeding tube in the appropriate } \\
\text { clinical setting, and the insertion procedures will minimize the risk of contamination } \\
\text { - The procedure used to handle food will minimize the risk of contamination } \\
\text { - Hospital team members will be proficient in the management of sudden terminal events } \\
\text { - There will be a plan detailing the management of obstetric patients and newborns } \\
\text { - Policies and procedures for transfusion of blood products will be clearly documented } \\
\text { - There will be a clear process to decide and plan discharge from hospital }\end{array}$ & 19 & 11 & $\begin{array}{l}5 \text { yes } \\
5 \text { no } \\
1 \text { in progress }\end{array}$ \\
\hline $\begin{array}{l}\text { Ebola-specific } \\
\text { diagnosis and } \\
\text { treatment }\end{array}$ & $\begin{array}{l}\text { - Hospital team members will order the most suitable test to diagnose Ebola } \\
\text { - Physicians will order and have access to the most appropriate therapy to target Ebola virus } \\
\text { disease }\end{array}$ & 2 & 0 & \\
\hline $\begin{array}{l}\text { Critical care } \\
\text { staffing issues }\end{array}$ & $\begin{array}{l}\text { - There will be sufficient staff available at all times with the required expertise and PPE training to } \\
\text { provide patient care and maintain the patient area } \\
\text { - The roles and responsibilities of hospital team members directly or indirectly involved in the } \\
\text { care of patients with suspected or proven Ebola will be clearly defined } \\
\text { - Hospital team members who have cared for patients with Ebola will monitor themselves for } \\
\text { signs of infection }\end{array}$ & 3 & 3 & $\begin{array}{l}2 \text { no } \\
1 \text { in progress }\end{array}$ \\
\hline $\begin{array}{l}\text { Visitation and } \\
\text { contacts }\end{array}$ & $\begin{array}{l}\text { - Visitation rights will be clearly defined } \\
\text { - Support will be provided to patients and their family members } \\
\text { - There will be a clear process on how to manage the treatment of anyone who has had } \\
\text { unprotected contact with a patient with suspected or confirmed Ebola } \\
\text { - There will be a clear process on how to screen visitors to the ICU and manage the treatment of } \\
\text { any visitor who tests positive for Ebola } \\
\text { - There will be a clear process on how to manage the treatment of any visitor who has a positive } \\
\text { screening test for Ebola }\end{array}$ & 5 & 4 & 4 no \\
\hline $\begin{array}{l}\text { Waste } \\
\text { management, } \\
\text { environmental } \\
\text { cleaning, } \\
\text { management of } \\
\text { linens }\end{array}$ & $\begin{array}{l}\text { - Waste will be safely removed from the room } \\
\text { - Processes will be in place to handle spills } \\
\text { - Processes will be in place to clean and disinfect surface areas } \\
\text { - Measures will be taken to avoid contamination and facilitate cleaning } \\
\text { - There will be a clear process in place to handle and clean used linen } \\
\text { - Processes will be in place to clean and disinfect nondisposable equipment }\end{array}$ & 6 & 5 & $\begin{array}{l}1 \text { yes } \\
3 \text { no } \\
1 \text { in progress }\end{array}$ \\
\hline Postmortem & - There will be a clear process in place to handle a deceased patient & 1 & 1 & 1 in progress \\
\hline $\begin{array}{l}\text { Conflict } \\
\text { resolution }\end{array}$ & $\begin{array}{l}\text { - There will be a clear process in place to respond to family members/visitors who refuse to } \\
\text { cooperate with the established policies } \\
\text { - There will be a clear process in place to respond to patients who are uncooperative and/or } \\
\text { aggressive }\end{array}$ & 2 & 2 & 2 no \\
\hline
\end{tabular}




\begin{tabular}{|c|c|c|c|c|}
\hline \multirow[b]{2}{*}{ Theme } & \multirow[b]{2}{*}{ Desired results } & \multicolumn{3}{|c|}{ No. } \\
\hline & & Results & Gaps & $\begin{array}{l}\text { Solutions } \\
\text { implemented } \\
\text { for gaps* }\end{array}$ \\
\hline Communication & $\begin{array}{l}\text { - There will be a clear process of communication to ensure that hospital and departmental } \\
\text { leaders collaborate } \\
\text { - There will be a clear process of communication, which will ensure that hospital team members } \\
\text { are well informed and up to date } \\
\text { - Communication will be established with other institutions designated as Ebola centres }\end{array}$ & 3 & 2 & 2 in progress \\
\hline & Totals & 73 & 55 & $\begin{array}{l}8 \text { yes } \\
29 \text { no } \\
18 \text { in progress }\end{array}$ \\
\hline
\end{tabular}

\section{Results}

A summary of the findings is presented in Table 2. In total, 15 themes and 73 desired results were identified, of which 55 were considered to be gaps. For the gaps identified, 8 were fully addressed with solutions, 18 had solutions in progress and 29 had not yet had solutions initiated at the end of the study period. A total of 20 international and Canadian documents were reviewed in full and incorporated into the results. In addition, all documents posted by the hospital with respect to Ebola virus disease were reviewed. Given the vast amount of data, it is not possible to present the entirety of our findings in this paper. The complete data set is available in Appendix 1 (available at www.cmajopen.ca/content/3/2/ E198/suppl/DC1). We present 3 results as illustrative examples.

\section{Theme 1: personal protective equipment}

There will be a clear process of donning and doffing appropriate personal protective equipment (PPE) that will protect hospital team members caring for patients with potential or confirmed Ebola.

In keeping with provincial standards, the initial PPE training for caring for patients with suspected or proven Ebola included a fluid-resistant gown, 1 pair of gloves ( 2 if drawing blood), surgical mask, goggles and a face shield. Later, neck and boot covers were added. Participants felt that this equipment and process were inadequate and did not offer sufficient protection. In addition, participants identified errors in the videos that were provided to enhance training, and the quality of the face-to-face training was also questioned. Furthermore, many participants described feeling that their concerns were not being acknowledged or taken seriously by the infection control staff, which contributed to a lack of trust. The infection control staff were also concerned that the education pro- vided would not be well received and described experiencing much anxiety and worry at that time.

Hospital team members wanted to ensure that proper procedures were in place for decontamination to remove bodily fluid on their PPE before doffing. For example, they proposed using bleach to decontaminate any soiled surfaces before exiting the patient room. Suggestions were also made to use dedicated footwear, a decontamination mat to clean footwear before exiting the anteroom, and an apron to be removed in the patient room before entering the anteroom. The apron was noted to be particularly important for use when caring for critically ill patients.

In October 2014, the Ministry of Health and Long-term Care released new directives to enhance the PPE measures used by hospital team members. Following this release, specialists from The Ottawa Hospital Infection Prevention and Control Program sourced equipment and rapidly developed a curriculum on PPE donning and doffing with the new equipment. Interviews with hospital team members after their training session showed increased satisfaction with the training and equipment. Hospital team members were impressed with the speed with which the program was put together and also described a positive and receptive learning environment; the infection control professionals appeared more open and engaged in listening to their comments and suggestions. However, participants noted that removing the hooded coveralls was very difficult and that they would need more practice to attain proficiency. They suggested that certification should reflect proficiency and not only participation in the training session.

It was noted that Ministry of Health and Long-term Care recommended the use of a powered air purifying respirator (PAPR) suit when performing aerosol-generating procedures (e.g., intubation). This equipment had not been acquired, and participants did not know whether the PAPR suit should be used only with intubation or also during other aerosol-generating procedures. 


\section{Theme 2: patient placement and room setup}

The most suitable rooms to provide treatment to patients with suspected or proven Ebola will be selected and then redesigned and re-equipped if required.

Participants were concerned that the room designated as the Ebola room in the ICU was less than ideal. Multiple questions were raised pertaining to the room layout, storage of equipment, identification of contaminated versus clean areas, impact on the provision of care, and interference with family visitation for other ICU patients. Hospital team members suggested that we should consider a different location for the room.

Iterative data were gathered from hospital team members to identify criteria for selection of an Ebola room, which included considering the safest route of entry in the ICU, sufficient space outside the anteroom for equipment, isolation from other traffic including visitors and staff, ability to use adjacent rooms in the event of more than 1 patient and ability to perform simulations. These criteria were then applied in the selection of a new Ebola room. Subsequently, after numerous interviews and walk-throughs, a new room was identified that met the selection criteria. The room was also redesigned and re-equipped to minimize the risk of transmission while optimizing patient care. In collaboration with the facility team, the computer, shelves and built-in desk were removed and the room repainted. Hazard tape was trialed in various configurations to best define clean and contaminated areas to optimize usage of the room by all key stakeholders (i.e., doffing practices and waste removal) (Appendix 2, available at www.cmajopen.ca/content/3/2/E198/suppl/DC1).

\section{Theme 3: Intrahospital transport}

The transport process will be clearly defined and will include only essential staff.

Participants were concerned that a process to ensure patient and staff safety during transport to and from the ICU was not in place. The emergency department was identified as the most important source of patient transfers to the ICU, and it was decided to first develop the transport process from the emergency department to the ICU. Numerous suggestions were made to improve safety during transfer: performing interventions (e.g., nasogastric intubation and Foley catheter insertion) before transfer, ensuring that the path is not cluttered and that people not wearing PPE are kept at a safe distance, defining roles and responsibilities of the staff both inside and outside of the emergency department Ebola room, identification and cleaning of contaminated surfaces and spills that might occur during transport, and using a minimal number of staff members (including spotters) while maintaining patient safety. A transport process was iteratively developed through many walk-throughs with key stakeholders. Each step was carefully explored. For example, it was decided that the process would include an initial readiness assessment by the
ICU team conducted before entering the emergency department Ebola room to determine whether additional measures should be taken before transport to manage bodily fluid (Appendix 3, available at www.cmajopen.ca/content/3/2/E198 /suppl/DC1).

\section{Interpretation}

This investigation has revealed widespread gaps in the provision of critical care for suspected or confirmed cases of Ebola across 15 themes. The identification of gaps is not surprising given that this centre has never planned for or cared for patients with Ebola or viral hemorrhagic fever, and the hospital structures, systems and processes have not been built to handle these cases. These results, however, are concerning and highlight substantial deficits in preparedness, which we suspect exist in many other hospitals.

In our investigation, we have defined what "should be." This is an essential first step in a needs assessment. ${ }^{8}$ It also initiates the process for setting standards in caring for patients with suspected or confirmed Ebola. It is imperative that we are clear on our terminology in terms of actions. That is, it is essential to differentiate between standards, guidelines and recommendations. The term "standard" represents any definitive rule, principle or measure established by authority and may not be subjected to individual changes, therapeutic or diagnostic modifications. In contrast to standards, guidelines define the present quality of treatment, but are sufficiently flexible to allow rapid changes if these are required. Recommendations are still further removed from a rigid set of standards to be referred to for advice on a course of treatment. ${ }^{32}$

Of the many standard-setting processes reviewed, we found the National Aeronautics and Space Administration (NASA) Space Flight Health Standards-Setting Process (2007) to be exemplary and closest to the approach taken here. ${ }^{33}$ Hallmarks of NASA's standard-setting processes include an approach that is evidence-based, open and transparent (all interested parties have input into the process), well documented (trail of decision-making process), well informed (experts, decision- and policy-makers) and dynamic (iterative and ongoing). ${ }^{33,34} \mathrm{~A}$ thorough literature review is the starting point of any standards-setting process and should encompass the relevant literature. Our process included a compilation of existing standards (e.g., guidelines and protocols released by the WHO, CDC and Emory Healthcare). Guidelines from CCCS, CAEP, AMMI Canada, the Ministry of Health and Long-term Care of Ontario, and relevant local-level hospital documents were collated and refined into a single document (Appendix 1). We found having a single point of reference enhances communication and knowledge transfer to key individuals and throughout the organization.

Similarly, a collaborative, open and transparent focus with substantial opportunities for revision and improvement are an inherent part of a high-quality standards-setting process. . $^{33,35}$ Adopting an "open door policy," bringing together a broader interdisciplinary team and involving front-line staff were key components of our study. The term "hospital team member" 
was used to recognize the vital roles of the many individuals from various backgrounds who contribute to the care of patients with potential or confirmed Ebola. At the onset of the study, front-line hospital team members felt they were either misinformed or poorly informed regarding the preparedness planning. They described feeling that no information was being provided, and some participants believed that lack of information might have added to the anxiety of hospital team members. The needs assessment highlighted that multiple groups were working on identifying problems and solutions, but communication between the groups and a shared understanding was initially lacking.

The literature has highlighted in previous pandemics that front-line staff perceived that information was not always available. ${ }^{5}$ Nhan and colleagues ${ }^{36}$ described how a top-down management approach to the influenza A (H1N1) pandemic in Canada was criticized and caused much frustration. They surveyed 102 physicians and identified 2 core themes with respect to problems with pandemic management: coordination and resource-related difficulties. Their qualitative analysis suggested that "most difficulties experienced during [pandemic] H1N1 were related to coordination of response between stakeholders." 36 The Roundtable on Healthcare and Emergency Service Sector Pandemic Preparedness reported that a top-down approach is essential in emergencies management, but that a bottom-up method of feedback is also needed to allow adaptation to varying circumstances. ${ }^{36,37}$ By performing a comprehensive needs assessment involving all key stakeholder groups, we merged these 2 approaches, facilitating communication and collaboration between leaders and front-line hospital team members, strengthening the overall result, enhancing buy-in to solutions and producing a transparent process.

Many lessons were learned from the experiences with H1N1 and SARS. Standard operating procedures in the event of an influenza epidemic have been drafted, ${ }^{38-40}$ and centres should have procedures in place to respond., ${ }^{4,5}$ Recent events in the United States with the occupational transmission of Ebola to hospital team members has brought attention to concerns that hospitals may not be prepared to respond to these cases. Recent literature has questioned the strength of preparedness plans and raised concerns about the systems and processes in place to care for and contain these patients. ${ }^{3,41}$ Many countries do not have hospitals equipped with clinical units designed for special containment. Strategies are required to rapidly identify and bridge these gaps, recognizing the constraints to strengthening preparedness in every country. Education in infection prevention and control is clearly an important component of such strategies.

The results of our investigation show the need to contextualize practices to the local environment and explore practical considerations. This is well aligned with the CDC standardsetting consultations processes, which indicate that solutions are being developed at state and local levels to meet gaps that are driven by local needs. ${ }^{35}$ Many guidelines and resources exist to guide us in caring for these patients, but practices must be contextualized to the local environment with consid- eration to human, physical and social capital. ${ }^{42}$ For example, at the time of this study, international and provincial guidelines made clear recommendations on requirements for patient placement, such as ensuring a single room with negative pressure, a dedicated toilet, and a space and layout that allow for clear separation between clean and potentially contaminated areas. However, at the local level, ensuring adequate separation was constrained by the physical layout of the rooms, because the facilities were not originally designed to meet this requirement. Solutions had to take into consideration local barriers to optimize the situation and find inventive solutions.

This needs assessment was performed with a focus on the results. ${ }^{8}$ Many different solutions may lead to the desired result. In some cases, solutions were rapidly implemented to address high-priority gaps (e.g., obtaining PPE and preparing the ICU room). However, in other cases, solutions have not yet been identified. This approach may, in fact, facilitate collaboration by enhancing buy-in. ${ }^{8}$ At this centre, an iterative process will continue, with prioritization of gaps, and development and implementation of solutions, ensuring that effective solutions are in place and that all gaps are addressed. Hence, our matrix will continue to evolve. Once the "should be" conditions are clearly defined, cases of possible Ebola can be simulated using various modalities (e.g., technical skills, patient actors and a theatre-based approach) to test the system and to detect any additional gaps.

The immediate next step is to share this matrix with other hospitals (including those designated as Ebola patient care sites and community hospitals) to facilitate preparedness and practice change. We have been approached by individuals at other ICUs in Canada who have begun to use this matrix as the starting point for their local needs-assessment process. The results of this study and list of desired results are likely similar and transferable across ICUs. By focusing on results, ICUs can collect data to determine their current situation and measure and evaluate their progress in achieving the desired results. Based on their situation, they can delete sections and add local information. Transferability of an educational intervention from one site to another requires a compromise between the ideal of the intervention's original design and the contextual realities of the adoption site. ${ }^{43}$ It is our hope that through collaboration we may be in a better position to learn from ongoing local solutions.

\section{Limitations}

Several limitations of this needs assessment should be noted. Due to an extremely tight timeframe, we began with our centre and thus are not currently able to generalize our findings to other tertiary and community hospitals. Although we have attempted to include all key stakeholders in our needs assessment, it was not feasible to obtain a wider sample to include other stakeholders such as security, social work and the wider public. Additionally, it was a practical decision to begin with the critical care unit because this is where our expertise lies. Because many solutions involve multiple players, finding solutions will become a collaborative effort involving other departments and stakeholders. 


\section{Conclusion}

This investigation identified widespread gaps across numerous themes and has provided a credible and measureable set of results, which have aligned key stakeholders toward a unified goal. ${ }^{44}$ The process, tools and results may be of interest to other acute care hospitals and could potentially be adapted to their local context, resources and site designation.

The Ebola epidemic has been described as a "black swan" event because it is a far outlier from the usual expectations and carries an extreme impact. ${ }^{45}$ Although the risk of an Ebola outbreak in Canada remains low, isolated cases would not be unexpected. ${ }^{3}$ Preparedness depends on the strength of health systems and processes, which have been called into question.

A systematic approach to identifying gaps is an essential step in health delivery research aimed at ensuring that safe practices are in place to care for patients with Ebola. With extensive international travel across countries and a variety of highly infectious agents spread through direct contact, it is important to also think beyond Ebola to be prepared for future possibilities, and to be proactive in preparation rather than reactive. ${ }^{41}$

\section{References}

1. Ebola virus disease. Fact sheet No. 103. Geneva: World Health Organization; 2014. Available: www.who.int/mediacentre/factsheets/fs103/en/ (accessed 2014 Nov. 7).

2. Ebola situation report. Geneva: World Health Organization; 2015. Available: http://apps.who.int/ebola/current-situation/ebola-situation-report11-march-2015 (accessed 2015 Mar. 11)

3. Gostin LO, Hodge JG, Burris S. Is the United States prepared for Ebola? 7AMA 2014;312:2497-8.

4. Booth CM, Stewart TE. Severe acute respiratory syndrome and critical care medicine: the Toronto experience. Crit Care Med 2005;33(1 Suppl):S53-60.

5. Gabriel LEK, Webb SAR. Preparing ICUs for pandemics. Curr Opin Crit Care 2013;19:467-73.

6. Straus S, Tetroe J, Graham ID, editors. Knowledge translation in bealth care: moving from evidence to practice. Chichester: John Wiley \& Sons; 2013.

7. Creswell JW. Research design: qualitative, quantitative, and mixed methods approaches. 4th ed. Thousand Oaks (CA): SAGE Publications; 2014.

8. Watkins R, Meiers MW, Visser Y. A guide to assessing needs: essential tools for collecting information, making decisions, and achieving development results. Washington: The World Bank; 2012.

9. Giacomini MK, Cook DJ. Users' guides to the medical literature: XXIII. Qualitative research in health care A. Are the results of the study valid? EvidenceBased Medicine Working Group. 7AMA 2000;284:357-62.

10. Miles MB, Huberman AM, Saldaña J. Qualitative data analysis: a methods sourcebook. Thousand Oaks (CA): SAGE Publications; 2014.

11. Case definition for Ebola virus disease (EVD). Atlanta: U.S. Department of Health and Human Services Centers for Disease Control and Prevention; 2014. Available: www.cdc.gov/vhf/ebola/hcp/case-definition.html (accessed 2014 Oct. 28).

12. Considerations for discharging persons under investigation (PUIs) for Ebola virus disease (EVD). Atlanta: U.S. Department of Health and Human Services Centers for Disease Control and Prevention; 2014. Available: www.cdc.gov/vhf/ebola/ hcp/considerations-discharging-pui.html (accessed 2014 Nov. 6).

13. Interim U.S. guidance for monitoring and movement of persons with potential Ebola virus exposure (updated 2014 Nov. 3). Atlanta: U.S. Department of Health and Human Services Centers for Disease Control and Prevention; 2014. Available: www.cdc.gov/vhf/ebola/exposure/monitoring-and-movement-of-persons-withexposure.html (accessed 2014 Nov. 4).

14. Guidance on personal protective equipment to be used by healthcare workers during management of patients with Ebola virus disease in U.S. hospitals, including procedures for putting on (donning) and removing (doffing). Atlanta: U.S. Department of Health and Human Services Centers for Disease Control and Prevention; 2014. Available: www.cdc.gov/vhf/ebola/hcp/procedures-for-ppe.html (accessed 2014 Oct. 21).

15. Safe management of patients with Ebola virus disease (EVD) in U.S. hospitals. Atlanta: U.S. Department of Health and Human Services Centers for Disease Control and Prevention; 2014.

16. Interim guidance for specimen collection, transport, testing, and submission for patients with suspected infection with Ebola virus disease: ebola hemorrhagic fever. Atlanta: U.S. Department of Health and Human Services Centers for Disease Control and Prevention; 2014. Available: www.cdc.gov/vhf/ebola/hcp/interimguidance-specimen-collection-submission-patients-suspected-infection-ebola. html (accessed 2014 Oct. 21)

17. Infection prevention and control recommendations for hospitalized patients with known or suspected Ebola hemorrhagic fever in US hospitals. Atlanta: U.S. Department of Health and Human Services Centers for Disease Control and Prevention; 2014 Available: www.cdc.gov/vhf/ebola/hcp/infection-prevention-and-controlrecommendations.html (accessed 2014 Oct. 21).

18. Guidance for safe handling of human remains of Ebola patients in U.S. hospitals and mortuaries. Atlanta: U.S. Department of Health and Human Services Centers for Disease Control and Prevention; 2014. Available: www.cdc.gov/vhf/ebola/hcp/ guidance-safe-handling-human-remains-ebola-patients-us-hospitals-mortuaries. html (accessed 2014 Nov. 7).

19. Recommendations for safely performing acute hemodialysis in patients with Ebola virus disease in U.S. hospitals. Atlanta: U.S. Department of Health and Human Services Centers for Disease Control and Prevention; 2014. Available: www.cdc. gov/vhf/ebola/hcp/guidance-dialysis.html (accessed 2014 Oct. 24).

20. Emory healthcare Ebola prepareness protocols. 2014. Available: www.emoryhealthcare. org/ebola-protocol/ehc-message.html (accessed 2014 Oct. 25).

21. Checklist for patients being evaluated for Ebola virus disease (EVD) in the United States. Atlanta: Centers for Disease Conrol and Prevention; 2014. Available: www.cdc.gov/vhf/ebola/pdf/checklist-patients-evaluated-us-evd.pdf (accessed 2014 Nov. 6)

22. Interim guidance for environmental infection control in hospitals for Ebola virus (updated 2014 Nov. 3). Atlanta: U.S. Department of Health and Human Services Centers for Disease Control and Prevention; 2014. Available: www.cdc.gov/vhf/ebola/ hcp/environmental-infection-control-in-hospitals.html (accessed 2014 Nov. 5).

23. Ebola virus disease (Ebola): algorithm for evaluation of the returned traveler. Atlanta: U.S. Department of Health and Human Services Centers for Disease Control and Prevention; 2014. Available: www.cdc.gov/vhf/ebola/pdf/ebola-algorithm. pdf (accessed 2014 Oct. 21).

24. Clinical management of patients with viral haemorrhagic fever: a pocket guide for the front-line health worker. Geneva: World Health Organization; 2014.

25. Personal protective equipment in the context of filovirus disease outbreak response. Geneva: World Health Organization; 2014. Available: http://apps.who.int/iris/ bitstream/10665/137410/1/WHO_EVD_Guidance_PPE_14.1_eng.pdf (accessed 2014 Nov. 8).

26. Interim infection prevention and control guidance for care of patients with suspected or confirmed filovirus haemorrhagic fever in health-care settings, with focus on Ebola. Geneva: World Health Organization; 2014. Available: www.who.int/csr/ resources/publications/ebola/filovirus_infection_control/en/ (accessed 2014 Oct. 21).

27. Canadian Critical Care Society, Canadian Association of Emergency Physicians, Association of Medical Microbiology and Infectious Diseases Canada. Ebola clinical care guidelines: a guide for Canadian clinicians. Report \#2-Updated: October 28, 2014. Available: http://cccsnew.businesscatalyst.com/website/ Guidelines/Ebola\%20Clinical\%20Care\%20Guidelines-2014-10-28.pdf (accessed 2014 Oct. 28).

28. Chief Medical Officer of Health. Ebola virus disease directive \#1 for hospitals. Toronto: Ontario Ministry of Health and Long-Term Care; 2014 Oct. 30.

29. Public bealth management of cases and contacts of human illness associated with Ebola virus disease (EVD). Ottawa: Public Health Agency of Canada; 2014. Available: www.phac-aspc.gc.ca/id-mi/vhf-fvh/cases-contacts-cas-eng.php (accessed 2014 Nov. 7).

30. Interim guidance - Ebola virus disease: infection prevention and control measures for borders, healthcare settings and self-monitoring at home. Ottawa: Public Health Agency of Canada; 2014. Available: www.phac-aspc.gc.ca/id-mi/vhf-fvh/ebola -ipc-pci-eng.php (accessed 2014 Nov. 7).

31. Initial assessment and management of the returning traveller from countries/areas affected by Ebola virus disease: primary care providers. Toronto: Public Health Ontario; 2014

32. Dick WF. Setting standards and implementing quality improvement in trauma care. Eur 7 Emerg Med 1996;3:270-3.

33. Institute of Medicine. Review of NASA's space flight health standards-setting process. Washington: National Academies Press; 2007.

34. Ball JR, Evans CH, editors; Committee on Creating a Vision for Space Medicine During Travel Beyond Earth Orbit, Board on Health Sciences Policy, Institute of Medicine. Safe passage: astronaut care for exploration missions. Washington: National Academies Press; 2001.

35. Fichtner R. The CDC/ATSDR standards setting process for common data elements. 2014. Available: http://webapp1.dlib.indiana.edu/virtual_disk library/index.cgi/3725325/FID3800/speakers/fichtner.PDF (accessed 2014 Oct. 21).

36. Nhan $C$, Laprise $R$, Douville-Fradet $M$, et al Coordination and resourcerelated difficulties encountered by Quebec's public health specialists and infectious diseases/medical microbiologists in the management of A (H1N1) - a mixed-method, exploratory survey. BMC Public Health 2012;12:115.

37. CSA Standards Roundable on Healthcare and Emergency Service Sector Pandemic Preparedness. Voices from the H1N1 influenza pandemic front lines: a white paper about how Canada could do better next time. Mississauga (ON): CSA Standards; 2010.

38. Sprung CL, Cohen R, Adini B; European Society of Intensive Care Medi- 
cine's Task Force for intensive care unit triage during an influenza epidemic or mass disaster. Chapter 1. Introduction. Recommendations and standard operating procedures for intensive care unit and hospital preparations for an influenza epidemic or mass disaster. Intensive Care Med 2010;36 Suppl $1: \mathrm{S} 4-10$.

39. Joynt GM, Loo S, Taylor BL, et al. Chapter 3. Coordination and collaboration with interface units. Intensive Care Med 2010;36(Suppl 1):S21-31.

40. Sprung CL, Kesecioglu J; European Society of Intensive Care Medicine's Task Force for intensive care unit triage during an influenza epidemic or mass disaster. Chapter 5. Essential equipment, pharmaceuticals and supplies. Intensive Care Med 2010;36(Suppl 1):S38-44.

41. Ki M. What do we really fear? The epidemiological characteristics of Ebola and our preparedness. Epidemiol Health 2014;36:e2014014.

42. Sarti AJ, Sutherland S, Landriault A, et al. Comprehensive assessment of critical care needs in a community hospital. Crit Care Med 2014;42:831-40.

43. Varpio L, Bell R, Hollingworth $\mathrm{G}$, et al. Is transferring an educational innovation actually a process of transformation? Adv Health Sci Educ Theory Pract 2012;17:357-67.

44. Pronovost PJ, Goeschel CA. Time to take health delivery research seriously. 7AMA 2011;306:310-1

45. Osterholm MT, Moore KA, Gostin LO. Public health in the age of ebola in West Africa. FAMA Intern Med 2015;175:7-8.
Affiliations: Division of Critical Care (Sarti, Kim, Dupuis, Thornton, Mansour, Cardinal), Department of Medicine, The Ottawa Hospital; The Academy for Innovation in Medical Education (Sarti, Sutherland, Robillard, Cardinal), University of Ottawa; Practice, Performance and Innovation Unit (Sarti, Cardinal), The Royal College of Physicians and Surgeons of Canada, Ottawa, Ont.

Contributors: Aimee Sarti, Stephanie Sutherland, John Kim and Pierre Cardinal were involved in study conception and design, and study supervision. All of the authors participated in data acquisition, analysis and interpretation. Aimee Sarti and Stephanie Sutherland drafted the manuscript, which all of the authors revised. All of the authors gave final approval of the version to be published and agreed to act as guarantors of the work.

Acknowledgements: The authors extend their sincere appreciation to all the participants who took the time to share their thoughts and experiences.

Supplemental information: For reviewer comments and the original submission of this manuscript, please see www.cmajopen.ca/content $/ 3 / 2$ / E198/suppl/DC1 